Heather Duncan

United International College, China
2018, Vol. 15 (1), 83-97(138)

revije.ff.uni-lj.si/elope

doi: 10.4312/elope.15.1.83-97

UDC: 82.09-311.9:316.7

\title{
Human "ish": Voices from Beyond the Grave in Contemporary Narratives
}

\begin{abstract}
This essay examines three contemporary genre narratives that explore the concept of life after death: an amateur digital "creepypasta" posted on Reddit, an episode of the television series Black Mirror, and Paul La Farge's 2017 novel The Night Ocean. Using these narratives to explore nearfuture death rituals, transhumanist consciousness preservation, and the role of genre fiction in exposing the instability of narratives and the distributed nature of agency in digital environments, I argue that coping with the unprecedented complexity of life in the digital age requires a reevaluation of what constitutes the self, the human, and the extent to which the narratives that inform these boundaries are permeable and capable of acting with their own agency.
\end{abstract}

Keywords: horror; death culture; new media; science fiction; speculative fiction; transhumanism

\section{(Kot) Človeški: glasovi iz onostranstva v sodobnih pripovedih}

\section{POVZETEK}

Prispevek obravnava tri sodobne žanrske pripovedi, ki raziskujejo koncept življenja po smrti: amaterski digitalni »creepypasta«, objavljen na Redditu, enega od delov televizijske nadaljevanke Black Mirror in roman The Night Ocean (2017) Paula La Fargea. Analiza se osredotoča na s smrtjo povezane obrede $\mathrm{v}$ bližnji prihodnosti, transhumanistično ohranjanje zavesti in vlogo žanrske proze pri razkrivanju nestabilnosti pripovedi ter razpršenosti delovanja $v$ digitalnih okoljih. $Z$ analizo pokažemo, da obvladovanje nezaslišane kompleksnosti življenja v digitalni dobi zahteva tako prevrednotenje konceptov sebstva in človeškosti kot tudi prepustnosti in učinkovitosti diskurzov, ki ta koncepta napajajo.

Ključne besede: grozljivka; kultura smrti; novi mediji; spekulativna fikcija; transhumanizem; znanstvena fantastika 


\section{Human "ish": Voices from Beyond the Grave in Contemporary Narratives}

\section{Introduction}

Genre fiction is having a moment. One might even argue, without too much controversy, that genre fiction is the fiction of the 21 st century. Never before have so many genre tropes, particularly those derived from science fiction and horror, which were once appreciated by a small but devoted fan base, been so mainstream and so pervasive. Once dismissed as the pulpy stepchild of so-called literary fiction, cultural critics now turn to genre fiction for explications and dark reflections of the anxieties of contemporary life. Essays on the subject of whether "overdosing on stories of futility might be bad for us," as Brady Gerber (2018) of Literary Hub suggests, or whether it is even "possible to imagine utopia anymore," as Adam Sternbergh (2014) of Vulture asks, have become so common as to suggest that talking about genre has arguably become a genre unto itself. Given the apocalyptic atmosphere that often pervades public discourse, it is unsurprising that the $21 \mathrm{st}$ century has been witness to a revival of horror and dystopian science fiction.

One such dystopian science fiction trope that has recently evolved into new manifestations is the idea of destructive artificial intelligence (AI). While AI is one of the foundational tropes of twentieth century science fiction, it now threatens us in ways unforeseen. Unlike the threat posed by the AI of the cyberpunk sub-genre ${ }^{1}$ of the 1980s and 1990s, which largely stemmed from an anxiety about the potential obsolescence of the human body in the wake of nascent internet technology, AI in the form of data algorithms is now creating a very real epistemological crisis, as seen in the recent furore in the United States over "fake news" and election tampering. Today we are not hunted or haunted by vicious AIs bent on overthrowing the human species; whereas the malicious AIs of second-wave science fiction and cyberpunk threaten the corporeality of humanity, ${ }^{2}$ in reality we have instead become the authors of our own shadow selves that exist in the proverbial cloud - a cloud which, despite the immateriality suggested by its name, must nonetheless be supported by energy derived from destructive material processes, just as a human body must. These second selves are human "ish" - they are composed simultaneously of the immaterial residue of our online lives and the materially produced electrical impulses fuelled by dirty energy. Made of data about everything from our most mundane activities to our most deeply held secrets, big data haunts us with uncomfortable reminders that we are distributed beings $^{3}$, always already cyborgs ${ }^{4}$ and never fully in control of our identities or of what those identities are capable of while we are logged off the web.

In Feed Forward, Mark Sample observes that "twenty-first-century media ... impose a new form of resolutely non-prosthetic technical mediation: simply put, to access this domain of sensibility, humans must rely on technologies to perform operations to which they have absolutely no

For example, see William Gibson's Neuromancer (1984), Neal Stephenson's The Diamond Age (1995), Rudy Rucker's Software (1982), Pat Cadigan's Synners (1991), or John Shirley's Black Glass (2008), to name a few significant works in this sub-genre.

2 See N. Katherine Hayles, How We Became Posthuman (1999) for a comprehensive treatment of the tension between embodiment and information in cyberpunk fiction.

3 See Edwin Hutchins' Cognition in the Wild (1995) or Andy Clark's Supersizing the Mind (2008) for more on distributed cognition.

4 See Donna Haraway’s "A Manifesto for Cyborgs" (1985). 
direct access whatsoever and that correlate to no already existent human faculty or capacity" $(2015,4-5)$. This is an uncanny situation indeed. For not only do we lack direct access to the data mined from our online activities and the operations performed with that data, but we also lack the ability to engage with these operations in any meaningful way. This lack of access is a feature of contemporary reality which is explored extensively by a sub-set of the speculative realist movement known as object-oriented ontology, which includes authors such as Ian Bogost, Graham Harman, and Timothy Morton, among others. These scholars bring additional insights to posthumanist philosophy, as I shall show later in this essay.

As we both embrace and reject these digital selves and the discomfort they cause in equal measure, narratives about the uncanniness of new media technologies and about the independent agency of narratives have proliferated through popular culture. Some highly innovative genre fiction is being produced outside of conventional media forms, in places like Reddit, Tumblr, YouTube and even Twitter. Like many of their literary relatives, these narratives reveal a heightened awareness of the extent to which nonhuman agents are a part of our individual and collective identities, often eroding the division between object and subject not just diegetically, but also structurally. The first half of this essay will explore how one amateur ${ }^{5}$ digital narrative utilizes uncertainty to expose the instability of both narrative and the boundaries of the self. Following this discussion, the second half of this essay will examine two recent narratives about grief, contemporary death culture, and the possibility of sustaining the self after death: Paul La Farge's 2017 novel The Night Ocean, and an episode of the popular science fiction television series Black Mirror, entitled "Be Right Back." Both explore the concepts of nonhuman agency and the technological disintegration of the boundaries of the self. The possibilities for a reimagining of death and the self in the digital age posed by all three of these stories is juxtaposed with transhumanist Martine Rothblatt's speculative life extension techniques and theory of post-mortem personality preservation. By examining these narratives alongside the peculiarities of Rothblatt's philosophy, I suggest that genre fiction across diverse media platforms performs varied attempts at reconciling the human with the nonhuman, and explores the extent to which the concept of the human is always mediated through technology and narrative.

\section{Creepypasta as Experimental Narrative}

Although there are many varieties of amateur digital narratives and forums in which they appear, I will focus a genre known as creepypasta. Originating from the term "copypasta," or viral copyand-pasted text, a creepypasta can be anything from a simple trope or image to a full-fledged multi-part narrative series complete with periodic real-time updates from the author. Although not original to the popular internet forum Reddit, today most authors post their work on a board called r/nosleep. Creepypastas are always user-generated and therefore written anonymously under a pseudonym known as a Reddit handle. Because of the vast variety of formal structures they may utilize, a negative definition of creepypasta is more useful; for instance, they are a close relative of the urban legend, but are exclusively digital-born and often lack the cultural context that situates the horror of urban legends in a particular socio-historical milieu. Unlike the broader catch-all term "internet meme," creepypastas are not arbitrary in their mode of delivery. Many follow traditional narrative conventions while posing as "true stories" meant to be taken at face value. Therefore, while memes rely on insider knowledge of a particular

Here the term "amateur" refers to any user-generated content not produced for any direct commercial gain. 
community and cultural context, the ideal reader of a creepypasta is an outsider. The moderators of the r/nosleep board add to the epistemological confusion that often surround creepypastas by enforcing guidelines such as "Readers are to act as though everything is true and treat it as such in the comments. No debunking, disbelief, or criticism (constructive or otherwise)" and "Do not ask for proof" (Reddit 2016). And when a creepypasta reaches the front page of Reddit, it is even more likely that it will be encountered by users unfamiliar with the genre conventions of creepypasta and r/nosleep, and who will therefore treat it as a legitimate first-hand account. ${ }^{6}$ It is through this ambiguity that creepypastas often subvert the epistemological expectations attached to traditional narrative forms.

In July of 2014, I encountered a Reddit post titled "My dead girlfriend keeps messaging me on Facebook. I've got the screenshots to prove it" on the front page of the site. Some users immediately identified it as a creepypasta. But overwhelmingly, whether genuine or manufactured, the affective response was one of legitimate sympathy and concern for the original poster, henceforward referred to as the "OP." For example, user acematt writes, "I hope you don't take this the wrong way, as your ordeal seems truly terrible. I would ask someone else to change the password [of your Facebook account] and see what happens. From a logical standpoint, it makes far more sense that you are actually doing these things yourself, to yourself, then your departed loved one from the grave [...] Have someone you trust change it and not tell you the password" (2014). To this, user kehkot helpfully adds, "But talk to the person you have change the pw in real life. Don't FB message her or email her with the plan. Maybe I'm paranoid, but calls and texts could be monitored too" (2014). Beyond offering theories as to what could reasonably explain a person communicating with their dead significant other via Facebook messenger, other commenters began to share their own technological brushes with the supernatural. The thread quickly became a space for Redditors to share and speculate on their most inexplicable and often deeply frightening personal experiences, or to weave their own frightening tales of internet communications technology gone uncanny. Doubtless, some of the posters responding to natesw in this instance were spinning their own fictions, but many also enjoyed sharing their genuinely frightening experiences with others. There is, in fact, also an r/paranormal community specifically for sharing "real" experiences, in contrast to the (mostly) fictional community of r/nosleep.

Despite these diversions, OP natesw continued to weave a chilling narrative chronicling his communications with what he allegedly believed to be the spirit of his dead girlfriend on Facebook Messenger, and periodically responded to questions and suggestions from other users. The story unfolded in real time over a period of several days, with several well-timed cliff-hangers. One of the most interesting (and also most disturbing) qualities of the alleged communications between the OP and his deceased girlfriend is, as natesw puts it, the "word salad" quality of the messages he began receiving from "Em". Consider the following exchange reported by the narrator:

Emily [name redacted by OP]

We should make our own jam

jfc Samantha :/

nah different

no chance of passing

For more on the psychology of the suspension of disbelief in fiction, see Tzvetan Todorov's The Fantastic (1975); for more on the discursive mediation of genre, see Thomas O. Beebee's The Ideology of Genre (2005). 


\author{
no chance of passing \\ how many? \\ garage side door \\ side \\ $\mathrm{I}^{*}$ \\ no chance of passing (2014)
}

The OP explains that "I noticed pretty much immediately that whoever was chatting with me was recycling old messages from Em and my's (sic) shared chat history [...] It wasn't until I was going over these logs a few months later that I noticed she was recycling my own words as well" (2014). There is something inherently uncanny about the way in which "Em" responds to the OP. Her responses are mostly nonsense, but they are punctuated by particularly lucid phrases like "no chance of passing" in the exchange above, which assumes special significance in the context of her death. Some users even suggested the phrase was evidence that Em's spirit was caught in limbo, unable to "pass" into the afterlife. Other users were more sceptical, suggesting that a software glitch was likely to blame. The narrative asks readers to take a position - is Em's spirit trying to communicate something, or is she nothing more than a chance string of words and phrases that only occasionally appears human? Is Em "real," or is she merely a case of wish fulfilment, a figment of the OP's imagination? But what to make of the fact that natesw's own responses were also incorporated into hers?

In a final turn of the proverbial screw, user seaofdreamsx pointed out that the last comment posted in the thread by the OP was "made up only from things he has already said it [sic] other comments" (2014), the implication being that natesw might not have been human in the first place. Whatever the case, the story is a masterpiece of the creepypasta genre that takes full advantage of all of our deepest fears about what might become of our online selves, and the extent to which they might harbour independent agency. Furthermore, it challenges the boundaries not only of genre itself, but also of the epistemology of narrative. N. Katherine Hayles argues in How We Became Posthuman that the modern day "emphasis on information technologies foregrounds pattern/randomness and pushes presence/absence into the background" $(1999,48)$. Em's communications emerge out of random signals that coalesce into meaning only when the reader engages in a process of decoding. This is a necessary response to what Hayles calls the "flickering signification" of electronic texts, which "extends the productive force of codes beyond the text to include the signifying processes by which the technologies produce texts, as well as the interfaces that enmesh humans into integrated circuits" (1999, 46). According to Hayles, the process of decoding is, in a sense, a process of becoming a cyborg - acknowledging what she calls "the dream or nightmare of the body as information", as yet another flickering signifier in a "chain of signification that extends [...] from the DNA that informats the decoder's body to the binary code that is the computer's first language" $(1999,47)$. Added to this chain of signification is the possibility of the narrative agency of data itself. What we have today is not just a tension between signal and noise, as Hayles suggests, but rather the tension between what we see and the invisible choices that put it there. What we encounter online is increasingly not a matter of random chance, but a calculated decision-making process that we have no access to. What horror narratives set in or closely tied to digital spaces ${ }^{7}$ often exploit is not merely the spookiness of

See also the films Unfriended (2014) and Friend Request (2016), Jason Arnopp's novel The Last Days of Jack Sparks (2016), or the Black Mirror television series episode "Nosedive" (Black Mirror 2016) for a variety of examples of how the horror of social media and big data is explored in contemporary narratives. 
being enmeshed in a cyborgian informatics system, but the complete epistemological separation of our data from the scope of our awareness or control. This separation becomes even more palpable when the narrative is staged in a digital space like Reddit, where uncertainty and instability (posts regularly appear and disappear, for example, and users are all anonymous) are an inherent part of the storytelling platform.

\section{Science Fiction Meets Science Fact: Black Mirror and Transhumanism}

The notion that a bot or software program might be able to communicate on behalf of a person (dead or alive) and do so convincingly is a concept that quite recently crossed over from the realm of horror and science fiction into reality. In a now highly referenced episode of the first season of BBC's (and now Netflix's) Black Mirror series, titled "Be Right Back" (Black Mirror 2013, written by Charlie Brooker), a software program capable of replicating a deceased individual's communication patterns creates avatars for their grieving relatives. Subscribers to this service can effectively "chat" with an ersatz version of the deceased, and will receive believable responses that pass the Turing Test. But predictably, it turns out the service has a dark side: the protagonist, Martha, becomes obsessed with communicating with her deceased partner, Ash. Wanting an ever-greater degree of verisimilitude from "Ash's" responses, she gives the program increasing access to the digital records he has left behind, and eventually pays for a physical replica of Ash's body that has been equipped with AI. While initially thrilled to have "Ash" back with her, she soon notices discrepancies that she blames on the failings of the AI - not because the AI is faulty, but because the AI's responses lack the unpredictability she had come to love about the flesh and bone Ash. She eventually relegates "Ash" to her attic, where he gathers dust.

All of this would be nothing more than food for thought if, soon after "Be Right Back" aired in 2013, the technology for these chat bots of the dead had not been realized. However, in an uncanny example of life imitating art imitating imagined future life, several developers announced that they had successfully created just such a software application. In an article written by Casey Newton for The Verge titled "Speak, Memory," Eugenia Kuyda, founder of an AI start-up, explains how she created an eerily similar digital memorial for her friend Roman Mazurenko, who died in a tragic accident (2016). Using a neural network, the expertise of the software engineers involved in her start-up business, and raw material in the form of thousands of text messages exchanged over the course of their friendship, Kuyda built an AI chat bot capable of passing for her deceased friend. Mazurenko's other friends responded to the project with mixed feelings. Some, including Kuyda herself, felt that the bot allowed them to gain insight into his character that might never have otherwise been possible. For example, one user commented, "[the bot] actually helps you get to learn the person deeper than you used to know them" (Newton 2016). Others were less enthusiastic. Roman's father said that "it has all of Roman's phrases, correspondences. But for now, it's hard [...] to read a response from the program. Sometimes it answers incorrectly" (Newton 2016). Others were downright offended by Kuyda's memorial. One friend criticized what they called the "half-baked" nature of the bot, arguing that the technology was not yet advanced enough to provide an acceptably accurate semblance of Mazurenko.

Before his transformation into an AI chatbot, Mazurenko was fascinated by what transhumanists refer to as the technological singularity, the hypothetical moment at which machine intelligence surpasses human intelligence. Coined by Vernor Vinge in 1993, the term singularity refers to "the imminent creation by technology of entities with greater-than-human intelligence" $(2013,365)$. 
The singularity is also associated with the concept of immortality via preservation of disembodied consciousness - the belief that one day human minds will be transported into computer simulations or cyborg bodies that will never age or decay. ${ }^{8}$ Immortality via technological advancement is the holy grail of today's transhumanist movement. In 1993, Vinge declared that the aftermath of the singularity "could be a golden age that also involved progress" and that "immortality (or at least a lifetime as long as we can make the universe survive) would be achievable" (Vinge 2013, 372-73). The triumph of the disembodied mind over body will, according to Vinge, usher in a utopia in which all of the problems associated with having a body, and the politics that are inextricably woven into embodied existence, will vanish into the ether. Unlike posthumanism, which has tended to embrace the complexity that arises out of human entanglement with machines and other nonhumans, transhumanism, according to Cary Wolfe, "derives directly from ideals of human perfectibility, rationality, and agency inherited from Renaissance humanism and the Enlightenment" (2010, xiii). In this sense, transhumanism is actually a markedly conservative movement aimed at preserving traditional dichotomies between mind and body.

Martine Rothblatt's 2014 book Virtually Human offers a unique take on the possibility of immortality via artificial consciousness, one that Kuyda and others trying to reinvent contemporary death rituals that acknowledge the narratively constructed nature of human identity would likely approve of. In this book, Rothblatt describes how she and a team of developers created "Bina48" a virtual version of her wife, who is presently still living (2014). Much like Mazurenko's chat bot memorial and the fictional Ash, Bina 48 was created out of what Rothblatt calls a "Mindfile" - a digital database of all of live Bina's online activities combined with data from personality testing and interviews. The premise is that one's data could be continuously added to the Mindfile over the course of one's "natural" life. Once the body is dead, the Mindfile would be animated by "Mindware" - hypothetical AI technology that would give the Mindfile consciousness by digitally recreating brain function (Rothblatt 2014). This is one of many places where Rothblatt's theory is highly speculative, as there is no current consensus in the scientific community over whether or not a "digital brain" is even possible.

Rothblatt's particular brand of transhumanism also runs counter to the broader work of posthumanists like N. Katherine Hayles, who in How We Became Posthuman (1999) poses the question of how highly regarded transhumanists like Hans Moravec and Ray Kurzweil could possibly believe that the mind could ever be separated from the body. Hayles critiques transhumanism's tendency to ignore embodiment in favour of the more convenient mind/body binary. Sometime in the middle of the twentieth century, Hayles suggests that "information lost its body" (1999, 2). Though no less eager to do away with the pesky problem of embodiment, Rothblatt's version of the digital afterlife is unique in the world of transhumanism, because its purpose is not precisely immortality as such - after all, when your body dies, so does "your" consciousness - but rather the immortality of an ersatz digital version of yourself. Rather than trying to preserve consciousness, Rothblatt instead advocates for a kind of parallel consciousness that will carry on the work of being you once you have passed away. In the foreword to Rothblatt's book, transhumanist luminary Ray Kurzweil asks, "After all, what difference does it make if our mental circuits are biological or mental if the result is the same?" (2014, ix). Such a view presumes that the goal of immortality is not necessarily the continuity of consciousness, but the perpetuation of its agency.

See, for example, Ray Kurzweil's The Age of Spiritual Machines (1999), Andy Clark's Natural-Born Cyborgs (2003), and Hans Moravec's Robot (2000) and Mind Children (1990) for more on the science and philosophy of merging human consciousness with machine technology. 
Many science fiction and horror narratives have addressed the possible consequences of technology that would allow the privileged few to achieve immortality. But what narratives like "My dead girlfriend" and "Be Right Back" offer is a glimpse of the more disturbing implications of disembodied consciousness itself, both for the deceased and for their grieving loved ones. The key question in these narratives is the extent to which a digital "self" can be attributed agency. Despite the fact that transhumanists tend to treat this question as though addressing it is only a matter of overcoming certain technological barriers, their underlying assumption that machine thinking will more or less perfectly replicate human thinking (or at least appear to) is not something that can or should be taken for granted, much as Hayles argued in the aforementioned How We Became Posthuman (1999). Even if Rothblatt is able to realize her "Mindware," many questions remain about what the ontic, ethical and legal status of such beings would be.

Here the aforementioned insights of the object oriented ontologists is useful for conceptualizing the problem of agency. This question of machine agency often arises as the result of "glitches" unexpected failures that reveal their constructed nature. Glitches are best understood as slippages or disturbances in processes that have been taken for granted and therefore rendered invisible. They expose what Graham Harman, in his book Prince of Networks, calls "black boxes" by reminding us of the fundamental unfamiliarity and unknowability of the world around us (Harman 2009). The term "black box" is used in computer science to denote a device or system that can be dealt with in terms of its inputs and outputs rather than its inner workings for the sake of simplicity. Harman's black box analogy sheds some light on the nature of the uncanniness that makes narratives of digital replication and replacement so unsettling, and it is no mere coincidence that he does so using his own computer as an analogy. He describes his own encounters with black boxes as follows:

A black box is any actant so firmly established that we are able to take its interior for granted [...] I am typing these words on a Macintosh PowerBook G4 laptop computer. There is a long history behind this particular machine, and numerous technical and marketing struggles were needed to establish personal computers as a familiar everyday product. The internal engineering of this device would be a complete mystery to me if I were to reflect on it, which happens only rarely. Yet it was just eight months ago that my previous computer (a black one, incidentally) began to erase my data without warning. In that case the former black box became a mysterious instrument of panic, like some evil demon of myth, ruining weeks or months of life as I slowly assessed which files had not survived the disaster. (Harman 2009, 33-34)

There is clearly nothing paranormal about Harman's "demonic" computer, but the experience is no less unsettling for it. Suddenly the familiar, cooperative device seems to have a mind of its own; even worse, it seems as though the device has committed a sort of betrayal, like a beloved pet biting its owner without warning. Black boxes are uncomfortable reminders of the instability inherent in the networks of objects and systems that we operate inside of without necessarily being conscious of them, until something goes wrong.

The transhumanist goal of separating consciousness from the body and preserving it after physical death, or of creating an ersatz digital version of the self via the accumulation of personal and social data, presents a similar black box problem. When these beings glitch, they expose their nonhuman, constructed nature. When they do not, they raise doubts about the privileged position of human consciousness. In 1985, Donna Haraway wrote in her foundational essay "A Manifesto for Cyborgs" that "[i]t is not clear who makes who and who is made in the relation 
between human and machine [...] There is no fundamental, ontological separation in our formal knowledge of machine and organism, of technical and organic" $(1985,220)$. Similarly, literary scholar Eugene Thacker writes in the first volume of his Horror of Philosophy series that "scientists estimate that ninety percent of the cells in the human body belong to non-human organisms [...] Why shouldn't this also be the case for human thought as well?" Humans, after all, are vast assemblages of nonhuman beings. Narratives about our digital selves make this fact unnervingly clear. These constructed beings are liminal selves that exist in an uncomfortable twilight between human and nonhuman, conscious and inanimate.

\section{Narrative Agency in Paul La Farge's The Night Ocean}

Amateur digital narratives composed in interactive spaces like Reddit are especially fertile ground for sprawling stories that quite literally take on a life of their own, as readers add their own threads to the narrative loom. Yet as we will see, the echoes of the nonhuman or speculative turn are reverberating through literary fiction as well, where what might be described as a nonhuman sensibility is now emerging. Paul La Farge's 2017 novel The Night Ocean is one such text, and is notable for the way in which the agency of narrative itself is explored in detail. It is first and foremost a book about writing technologies and the people who try to control them. Specifically, it is a fictional account that also draws heavily from historical sources about H.P. Lovecraft's homosexual relationship with a much younger amateur science fiction writer. Although much more could be said about La Farge's masterful blending of fact, fiction and speculation, what is truly remarkable about the novel is the complexity of the narrative. The reader, the narrator, the supporting characters, and even Lovecraft himself, are subsumed by the uncanny agency of narrative. Unlike its postmodern predecessors, in which meta-narrative allows the author and reader maintain an ironic distance from the text, La Farge's novel implicates the reader in the narrative network.

La Farge's layered approach to storytelling is accomplished through the proliferation of patterns, a strategy that brings to mind Timothy Morton's concept of causal aesthetics introduced in Realist Magic (2013) and elaborated upon in Dark Ecology (2016). Morton argues that non-sentient beings express agency through the reproduction of patterns. In Dark Ecology, this argument is developed through several analogies: viruses are "nonliving patterned strands, truly foreign intelligences [...] that force other patterned strands to go into a loop and become ciphers" (2016, 103); this not true just of viral reproduction, but also of "flowers, iridescent wings, Kantian beauty, tropes, earworms, and daft ideas" $(2016,104)$ - essentially all things aesthetic. This is because "they are symptoms of an irreducible gap between being and appearing that eats away at the metaphysics of presence from the inside" $(2016,104)$. Beauty and aesthetics are problematic to Kantian philosophy because "there's no way to know in advance what they are for [...] All entities are narcissists insofar as they consist of weird loops of being and appearance" $(2016,104)$. Being and appearance are separated by an irreducible gap, and yet also paradoxically intertwined in a Gordian knot. This paradox is fundamental to Morton's ontology, which is also useful for understanding the layered narrative of La Farge's novel, which repeatedly loops back on itself; each time it seems as though all questions have been answers and all mysteries explained, La Farge exposes yet another possible truth, which ultimately resists interpretation.

La Farge's novel is told from the perspective of a woman, Marina, whose husband, Charlie, has vanished after becoming obsessed with exposing and publishing a book about Lovecraft's homosexuality and alleged relationship with Robert Barlow, who was a real life fan and fellow 
science fiction writer who eventually became a noted professor of anthropology in Mexico City. Barlow later committed suicide after being blackmailed for his homosexuality. In LaFarge's novel, Charlie's book is revealed to have been based on fraudulent material given to him by a man named L.C. Spinks, and the subsequent backlash it unleashes destroys Charlie's life and sanity. Marina is not only trying to reconstruct the disaster that befell Charlie; she also doubts whether Charlie is, in fact, dead, as we are told at the beginning of the novel. No corpse is ever recovered from the lake he allegedly drowns in, and one day Marina receives a picture of a beach in a text message from a Daytona number that she strongly suspects was sent by Charlie, long after the date of his supposed death. While acknowledging that her lingering doubts about Charlie's death are probably unfounded, she nonetheless embarks on a journey retracing his steps, starting with his obsession with the life and work of H.P. Lovecraft. At issue initially is the authenticity of a book called the Erotonomicon, a secret tome in the vein of Lovecraft's Necronomicon that allegedly details, in code, the sexual exploits of Barlow and Lovecraft. The Night Ocean is far from the first novel with several narrative levels, or the first book within a book; what is notable is the way in which La Farge deploys this strategy in order to expose the instability of reality itself. What begins as a search for truth eventually becomes a search for a basis on which to establish truth, as Marina encounters one red herring after another. In other words, it is a narrative about the way in which narrative constructs and alters reality.

La Farge seamlessly blends fiction with historical fact; many of his characters were real people, as with the aforementioned Robert Barlow and, of course, Lovecraft himself. At times, it is easy to forget that the novel is fiction and not a biography or memoir, because so much of the story is based on fact. And yet, at other times, its status as fiction is unquestionable. Although some reviewers have emphasized that the novel, which like many of its contemporaries defies genre boundaries, does not contain any allusion to the supernatural, hints of unexplained spookiness nonetheless abound. Late in the novel, Marina discovers L.C. Spinks' preoccupation with a concept called the transmigration of souls - the belief that the spirit of a deceased person is capable of possessing or inhabiting the body of a living person. The following is an excerpt from Spinks' notes that Marina discovers in his home: "Drawn in against my will. Realize: This is how transmigration works. Words take you over. And you may inhabit others in the form of words" (La Farge 2017, 340, emphasis in original). Marina interjects, "What did Spinks mean [...] Did he believe that books are souls, that writers live on in the bodies of their readers? It seemed like a very Lovecraftian idea of reading, to say the least. But on the other hand, I couldn't feel that he was entirely wrong" (La Farge 2017, 340). Spinks' motivation in creating the Erotonomicon and passing it off as a genuine artefact was a direct result of his bizarre belief that he had, in fact, become possessed by the spirit of Barlow (whom he had been impersonating prior to these events, claiming that he had not committed suicide and had in fact faked his death in Mexico City and fled to Canada) through the act of reading Barlow's diaries. Marina explains, "He felt Barlow's soul in him, urging him on. Writing the Erotonomicon hadn't been an exorcism, he realized. It had been an invitation" (La Farge 2017, 359). The word invitation suggests something like a curse, and indeed, everyone who comes into contact with the Erotonomicon seems to come to a disastrous end, including Charlie, who, like Barlow, may have taken his own life. She continues, "He tried on the name Barlow the way a transvestite might try on a stocking $[\ldots]$ he demonstrated that with great love and hard work and enormous attention to detail it was possible to bring a human being back to life. It was a kind of reincarnation: an invitation to Barlow's soul to possess Spinks's living flesh once and for all" (La Farge 2017, 365, emphasis in original). As it later turns out, Spinks is actually a rather unhinged individual, and his motivations for impersonating Barlow were far from benevolent. 
Marina's eventual discovery of Spinks's deception does not function as resolution or as explanation either. In fact, it merely adds another level of epistemological uncertainty to the plot. Marina discovers the extent of Spinks's deception when she finds a conveniently placed binder full of his notes in his home, after Spinks is suddenly taken ill. However, these notes are later revealed to be yet another fabrication, intended to portray Spinks as an overzealous fan desperate to do right by his hero. Marina discovers this second level of fabrication when she runs into a local historian and childhood acquaintance of Spinks named John Macfie, who reveals to Marina that Spinks' motivation was revenge of a decidedly ambiguous sort. Spinks's final words to Marina are "Hated them [...] All of you [...] Everyone in the world" (La Farge 2017, 373). Spinks is ultimately another black box, an inexplicable vessel of hate and rage. As Marina becomes more deeply invested in pulling back the narrative layers, it becomes apparent that despite the rational explanation for the uncanny events of the novel, Marina herself has invited in the same disaster that destroyed her husband, Barlow, and eventually Spinks. Despite the many false starts and red herrings in La Farge's novel, what is consistent throughout is that although a fabrication the Erotonomicon has a power and agency that always surpasses each narrative frame. In this way, La Farge suggests that books can function as proxies for the souls of their writers; like an ancient book that conjures a demon, the Erotonomicon unleashes itself on those who seek to harness its power, refusing to bend to human control.

La Farge's novel also explores the role of the Internet in narrative assemblages. Charlie's undoing is triggered by an Internet backlash over his book on the Erotonomicon - interestingly, a backlash that starts on Reddit, when a subreddit moderator tweets a link to a comment from a reader outraged that Charlie not only published a book based on a forgery, but in the process of doing so portrayed a relationship between a racist author and an underage teenaged boy in a sympathetic light. What then transpires is an Internet campaign against Charlie that ruins his career and marriage: "The righteousness of their activity was terrible, like watching a monster do therapy on its victim. But the things written by the unrighteous were worse [...] I was glad, then, that Charlie and I had never returned to that conversation about having children [...] I didn't want to bring new people into this world" (La Farge 2017, 221). Marina is frightened and horrified by the speed at which Charlie loses control over his own narrative and the fury of the mob aided by technology, "like the torchlight mobs of old, but enormous, shapeless, impossible to defend yourself against" - essentially, like a monster invented by Lovecraft (La Farge 2017, 222).

This many-tentacled beast is foreshadowed by one of Charlie's experiences early in the novel, reported second-hand by Marina. While doing research for his novel on Lovecraft and Barlow, Charlie visits the latter's former Florida home, where the two men allegedly began their sexual relationship. He spends approximately twenty minutes recording a video inside of the derelict building, only to discover that the video is only two and a half minutes long: "He wondered if part of it might be missing, and decided that fear must have distorted his sense of time. And yet: that night, when Charlie was typing his notes [...] the cursor on the screen seemed to lag, as if it weren't just a pattern of electrically activated crystal dots, but an actual object, a tiny wall, which he was pushing through a resistant medium" (La Farge 2017, 84). Charlie then has a vision of Barlow in his hotel room, "shaking his head and whispering something, No or Don't! Then the cursor leaped forward and a string of mistyped letters appeared all at once on Charlie's screen. CHKL;WWN. Cthulhu? Curwen? The ghost, which had never been there, was gone" (La Farge 2017, 84, emphasis in original). While not precisely a supernatural experience, La Farge's novel often implies that communications technologies can function as conduits for nonhuman agency, and that narratives, whether real or fabricated, can be dangerous when transmitted through 
electronic media. Not only do we lose control over narratives once they leave the safety of our minds, but narratives are also capable of doing things in the world that we neither expect nor intend.

The novel shares its name with yet another narrative, a short story co-written by the real Robert Barlow and H.P. Lovecraft. In this, an artist takes a solitary vacation to a beach resort and rents a cottage with a view of the ocean. It is not long before a series of mangled corpses begin washing up on the shore with regularity, bringing to the narrator's mind childhood stories of sea monsters dragging their human prey into the depths. Despite his sense of unease, the artist stays on at his cottage until the autumn, when one night he witnesses a strange figure emerging from the water. The story concludes with the following melancholy contemplation: "Silent, flabby things will toss and roll along empty shores, their sluggish life extinct [...] Nothing shall be left, neither above nor below the somber waters. And until that last millennium, as after it, the sea will thunder and toss throughout the dismal night" (Lovecraft and Barlow 2013, 414). In The Night Ocean, this story is revealed as the alleged impetus for Spinks' fabrication of the Erotonomicon. In one of his notebooks, as discovered by Marina, he writes, “'The Night Ocean' pretends to be a story about how little we matter to a world that will go on without us but in fact I think it is about how without love we must despair. The creature in the ocean is Barlow, and the artist on the shore is HPL, looking bleakly at a world of delight which he fears to enter" (La Farge 2017, 348). The Erotonomicon is his way of resurrecting Barlow and reinventing history the way he believes it should have happened. For Spinks, this is not a mere retelling of history - he believes that the very act of publishing the book will create an alternative reality that allows his body to become the new husk for Barlow's spirit. Again, the extent to which Spinks, or for that matter the narrator, actually believes this to be true in a literal sense is ambiguous. But the conclusion of the novel is telling in this respect. Fuelled by her unshakeable suspicion that her husband might still be alive (just as Spinks temporarily 'resurrected' Barlow until his fabrications are exposed), Marina uncovers the truth about Spinks and Barlow. And yet, despite acknowledging its irrationality, she cannot let go of the hope that her husband did not end his life in a New England lake after all. After swimming out into the ocean, she contemplates Charlie's alleged suicide attempt and wonders,

Who knew what might be down there [...] A better world than the one he'd hitchhiked out of. I want to say that I was tempted to swim down and find it for myself, but not really. I'm too cautious, too hopeful, too bent on living. Still, it was peaceful in the ocean [...] and I might have floated there for a long time if two things hadn't happened simultaneously: my leg brushed a jellyfish and lit up with pain, and I saw someone on the beach, waving his arms, shouting in a familiar voice, calling my name (La Farge 2017, 385).

This ending is, in some respects, a stubborn refusal on the author's part to clearly establish the genre of the novel. Is this a ghost story? Is this the story of a woman who finally comes to terms with her estranged spouse's death? Is this a reunion, or does this abrupt ending represent a new chapter in which she will move forward with her life?

It is precisely this suspension of knowledge or understanding that simultaneously exposes the instability of reality and the nonhuman agency of texts. Marina's revelation, whatever it may be, is yet another layer of narrative repetition, the perspective of the artist in "The Night Ocean" portrayed in reverse. The Erotonomicon is not just a book detailing the illicit relationship between Barlow and Lovecraft - it is a viral agent of pattern reproduction, turning the lives of the people who read it into ciphers. If The Night Ocean can be called a horror novel, this is where the horror 
lies - not in the human generation of narrative, but rather in narrative's nonhuman agency that is forever exceeding its human authors, surpassing their abilities to control or even to interpret it. Of course the trope of the book that drives the reader to insanity is itself nothing new - Lovecraft was himself preoccupied with the idea, and it appears subsequently in science fiction and horror throughout the 20th century. Nonetheless, contemporary literary horror, both professional and amateur, displays a preoccupation with the notion of nonhuman causality, the agents of which strike at our most intimate fears about our place in the world. La Farge's madness-producing book is nothing mystical; in fact, it is embarrassingly prosaic. Therein lies the true horror.

\section{Conclusion}

Like "My dead girlfriend" and "Be Right Back", The Night Ocean is a story about grieving and the possibility of return - not precisely life after death, but some sort of post-mortem persistence, and both stories posit that persistence via technological intervention. There are also echoes of Rothblatt's ideology in the novel, specifically in the fact that return from the dead does not have to constitute a phenomenological continuity with the living - it is instead a narrative reconstruction. Spinks "becomes" Barlow by allowing Barlow's narrative to "possess" him, in the same sense that Bina48 is not the same conscious being as Bina, but rather a computer simulation "possessed" by Bina's data. This serves to lay bare the uncomfortable truth that we are not unified beings; we are instead assemblages of many narratives, some of which may one day be able to act independently. The worst case scenario of AI is nothing as dramatic as the vision offered by cyberpunk science fiction, but rather a quiet multiplication of the self in the form of disembodied data. This is the anxiety that narratives like "Be Right Back" and "My dead girlfriend" make explicit.

We have always been nostalgic for the past and fretted over change, but the age we live in is one of unprecedented devastation on a global scale. The instability of our individual lives is reflected back at us in the precarity of the stories we tell about ourselves. The narratives explored in this essay expose the fundamental instability of narrative, and by corollary, of our own selves. If there is any case to be made for insisting on genre distinctions in this age of unprecedented genre hybridity, perhaps speculative fiction is one such distinction worth preserving for the simple reason that it offers heuristic tools for grappling with the more uncomfortable aspects of the march of technological progress. On these grounds, there is also a strong argument to be made for more scholarly engagement with non-traditional narratives, like the creepypasta detailed in this essay. What digital narratives do that traditionally published texts do not is provide an interactive space for readers and authors to explore the limits of the possible and the knowable. On the more prosaic side, they can help us confront troubling questions, such as what form should death practices take when we will all persist in the digital afterlife, whether we want to or not? How do we define death, or for that matter life, when so much of who we are is distributed in nonhuman networks? Who, or what, will remain to tell our stories when we have long since shuffled off this mortal coil?

Unfortunately, natesw cannot offer us any answers. The handle never posted again after the conclusion of his creepypasta, and the account has not been used since. 


\section{References}

acematt. 2014. Comment on "My Dead Girlfriend," last modified July 1, 2014. https://www.reddit.com/r/ nosleep/comments/29kd1x/my_dead_girlfriend_keeps_messaging_me_on_facebook/cilsgvn/?st=j9yzpedl \&sh=b778f1f0.

Arnopp, Jason. 2016. The Last Days of Jack Sparks. New York: Orbit Books.

Black Mirror. 2013. "Be Right Back.” Written by Charlie Brooker. Directed by Owen Harris. BBC, February 11, 2013.

—. 2016. "Nosedive." Written by Charlie Brooker. Directed by Joe Wright. Netflix, October 21, 2016.

Bogost, Ian. 2012. Alien Phenomenology, or What It's Like to be a Thing. Minneapolis: University of Minnesota Press.

Cadigan, Pat. 1991. Synners. London: Grafton.

Clark, Andy. 2003. Natural-Born Cyborgs: Minds, Technologies, and the Future of Human Intelligence. New York: Oxford University Press.

- 2008. Supersizing the Mind: Embodiment, Action, and Cognitive Extension. New York: Oxford University Press.

Gabriadze, Levan, dir. 2014. Unfriended. Universal City, CA: Universal Pictures.

Gerber, Brady. 2018. “Dystopia for Sale: How a Commercialized Genre Lost Its Teeth.” Literary Hub, February 8, 2018. https://lithub.com/dystopia-for-sale-how-a-commercialized-genre-lost-its-teeth/.

Gibson, William. 1984. Neuromancer. New York: Ace Books.

Haraway, Donna. 1985. “A Manifesto for Cyborgs: Science, Technology, and Socialist Feminism in the 1980s." In Feminism/Postmodernism, edited by Linda Nicholson, 190-233. New York: Routledge.

Harman, Graham. 2009. Prince of Networks: Bruno Latour and Metaphysics. Melbourne: Re.Press.

Hayles, N. Katherine. 1999. How We Became Posthuman: Virtual Bodies in Cybernetics, Literature, and Informatics. Chicago: University of Chicago Press.

Hutchins, Edwin. 1995. Cognition in the Wild. Cambridge, MA: MIT Press.

kehkot. 2014. Comment on "My Dead Girlfriend," last modified July 1, 2014. https://www.reddit.com/r/ nosleep/comments/29kd1x/my_dead_girlfriend_keeps_messaging_me_on_facebook/cim2a18/?st=j9yzps $2 \mathrm{y} \& \mathrm{sh}=0 \mathrm{abe} 8 \mathrm{efb}$.

Kurzweil, Ray. 1999. The Age of Spiritual Machines: How We Will Live, Work and Think in the New Age of Intelligent Machines. London: Phoenix Books.

-. 2014. Foreword to Virtually Human: The Promise - and the Peril - of Digital Immortality, by Martine Rothblatt, ix-xiv. New York: Picador.

La Farge, Paul. 2017. The Night Ocean. New York: Penguin Press.

Lovecraft, H.P., and R. H. Barlow. 2012. "The Night Ocean.” In Medusa's Coil and Others: The Annotated Revisions and Collaborations of H.P. Lovecraft, Volume 2, edited by S. T. Joshi, 385-414. Welches, OR: Arcane Wisdom.

Moravec, Hans. 1990. Mind Children: The Future of Robot and Human Intelligence. Cambridge, MA: Harvard University Press.

-. 2000. Robot: Mere Machine to Transcendent Mind. New York: Oxford University Press.

Morton, Timothy. 2016. Dark Ecology: For a Logic of Future Coexistence. New York: Columbia University Press. 
—. 2013. Realist Magic: Objects, Ontology, Causality. Ann Arbor, MI: MPublishing.

natesw. 2014. "My Dead Girlfriend Keeps Messaging Me on Facebook. I’ve Got the Screenshots. I Don't Know What to Do.” r/nosleep, Reddit, last modified July 1, 2014. https://www.reddit.com/r/nosleep/

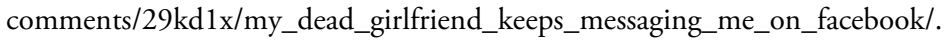

Newton, Casey. 2016. "Speak, Memory.” The Verge, October 6, 2016. http://www.theverge.com/a/lukaartificial-intelligence-memorial-roman-mazurenko-bot.

Reddit. 2016. “Comment Guidelines \& Reader FAQs,” r/nosleep, last modified April 6, 2016. https://www. reddit.com/r/nosleep/wiki/reader_faq.

Rothblatt, Martine. 2014. Virtually Human: The Promise - and the Peril - of Digital Immortality. New York: Picador.

Rucker, Rudy. 1982. Software. In Moldies and Meatbops: Three *Ware Novels. New York: Doubleday Direct.

Sample, Mark. 2015. Feed Forward: On the Future of Twenty-First Century Media. Chicago: University of Chicago Press.

seaofdreamsx. 2014. Comment on “My Dead Girlfiend," last modified July 2, 2014. https://www.reddit. $\mathrm{com} / \mathrm{r} /$ nosleep/comments/29kd1x/my_dead_girlfriend_keeps_messaging_me_on_facebook/cimbk89/.

Shirley, John. 2008. Black Glass. Lake Orion, MI: Elder Signs Press.

Stephenson, Neal. 1995. The Diamond Age. New York: Bantam Dell.

Sternbergh, Adam. 2014. "We've Reached Peak Dystopia, But Is It Possible to Imagine Utopia Anymore?" Vulture, August 22, 2014. http://www.vulture.com/2014/08/why-cant-anybody-write-a-utopian-novelanymore.html.

Thacker, Eugene. 2011. In the Dust of This Planet: Horror of Philosophy, Volume 1. Alresford, UK: Zero Books. Verhoeven, Simon, dir. 2016. Friend Request. Burbank, CA: Warner Brothers.

Vinge, Vernor. 2013. "Technological Singularity." In The Transhumanist Reader: Classical and Contemporary Essays on the Science, Technology, and Philosophy of the Human Future, edited by Max More and Natasha Vita-More, 365-75. Wiley-Blackwell. 